\title{
Seed dispersal and predation of Buchenavia tomentosa Eichler (Combretaceae) in a Cerrado sensu stricto, midwest Brazil
}

\author{
J. Farias ${ }^{a}$, M. Sanchez ${ }^{b}$, M. F. Abreu ${ }^{c}$ and F. Pedroni ${ }^{b *}$

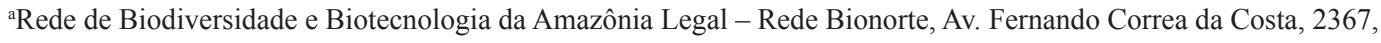 \\ Boa Esperança - UFMT/INPP, Bloco I-C, Sala 21, CEP 78060-900, Cuiabá, MT, Brazil \\ ${ }^{\text {b} L a b o r a t o ́ r i o ~ d e ~ E c o l o g i a, ~ I n s t i t u t o ~ d e ~ C i e ̂ n c i a s ~ B i o l o ́ g i c a s ~ e ~ d a ~ S a u ́ d e, ~ U n i v e r s i d a d e ~ F e d e r a l ~ d e ~ M a t o ~ G r o s s o ~-~ U F M T, ~}$ \\ Campus Universitário do Araguaia, Rod. MT 100, Km 3,5, CEP 78698-000, Pontal do Araguaia, MT, Brazil \\ 'Programa de Pós Graduação em Ecologia e Conservação, Universidade do Estado de Mato Grosso - UNEMAT, \\ Rod. BR 158, Km 655, CP 08, CEP 78690-000, Nova Xavantina, MT, Brazil \\ *e-mail: fpedroni@ufmt.br
}

Received: April 10, 2014 - Accepted: October 1, 2014 - Distributed: November 30, 2015

(With 3 figures)

\begin{abstract}
The ecology of seed dispersal is critical to understand the patterns of distribution and abundance of plant species. We investigated seed dispersal aspects associated with the high abundance of Buchenavia tomentosa in the Serra Azul State Park (PESA). We estimated fruit production and conducted fruit removal experiments. We carried out diurnal and nocturnal observations on frugivory as well as germination tests. Fruiting occurred in the dry season and totaled 1,365,015 $\pm 762,670$ fruits.ha ${ }^{-1}$. B. tomentosa fruits were utilized by eight animal species. The lowland tapir (Tapirus terrestris) was considered the main seed disperser. Leafcutter ants (Atta laevigata and Atta sexdens) participated in the seed cleaning and occasionally dispersed seeds. The beetle Amblycerus insuturatus, blue-and-yellow macaw (Ara ararauna) and red-and-green macaw (Ara chloropterus) were considered pre-dispersal seed predators. The seeds manually cleaned presented higher germination rate (100\%) and speed index $\left(4.2\right.$ seeds. $\left.\mathrm{d}^{-1}\right)$ than that of seeds with pulp. Germination of seeds found in tapirs'feces was $40 \%$, while for the seeds without pulp it was $25 \%$. The high abundance of $B$. tomentosa in the cerrado of PESA may be due to massive fruit production, low rates of seed predation, and efficient seed dispersal by tapirs, occurring before the rains which promote germination and recruitment of this species.
\end{abstract}

Keywords: exclusion experiments, fruit production, frugivory, seed germination, tapir dung.

\section{Dispersão e predação de sementes de Buchenavia tomentosa Eichler (Combretaceae) em Cerrado sentido restrito, centro-oeste do Brasil}

\section{Resumo}

A ecologia da dispersão de sementes é importante para entender a distribuição e abundância das espécies vegetais. Investigamos os fatores relacionados à elevada abundância de B. tomentosa no Parque Estadual da Serra Azul (PESA) avaliando aspectos da dispersão de sementes. Estimamos a produção de frutos e realizamos experimentos de remoção de frutos. Fizemos observações diurnas e noturnas sobre a frugivoria e testamos a germinação de sementes. A frutificação ocorreu na estação seca totalizando 1.365.015 \pm 762.670 frutos.ha ${ }^{-1}$. Oito espécies de animais utilizaram frutos de B. tomentosa. Anta (Tapirus terrestris) foi considerada o principal dispersor. Saúvas (Atta laevigata e Atta sexdens) participaram na limpeza das sementes e como dispersores ocasionais. O besouro Amblycerus insuturatus, arara-canindé (Ara ararauna) e arara-vermelha (Ara chloropterus) foram considerados predadores pré-dispersão. Sementes despolpadas manualmente tiveram maior percentual (100\%) e velocidade de geminação $\left(4,2\right.$ sementes.dia $\left.^{-1}\right)$ que aquelas com polpa. Sementes encontradas nas fezes de antas apresentaram 40,0\% de germinação e sementes sem polpa 25,0\%. A massiva produção de frutos, baixa taxa de predação de sementes, além da eficiente dispersão por antas, antes da estação chuvosa, favorecem o recrutamento e são fatores que contribuem de forma decisiva para a elevada abundância de $B$. tomentosa observada no cerrado do PESA.

Palavras-chave: experimento de exclusão, produção de frutos, frugivoria, germinação de sementes, fezes de anta. 


\section{Introduction}

The seed stage is the phase of the plant life cycle more susceptible to mortality. Seed dispersal has been considered a way to escape predation and improve chances of survival (Janzen, 1971). When dispersal fails, the offspring is usually condemned to extinction and the establishment in new sites becomes impossible.

Fruit morphology, presentation, and distribution are main factors influencing animals that visit fruiting plants. On the other hand, frugivores' behaviors such as number of visits, quantity of fruits consumed, spitting out, regurgitating, dropping or defecating seeds far from the parent tree (Côrtes et al., 2009) affect the efficiency of the seed dispersal process (Jordano and Schupp, 2000; Schupp, 1993). The passage of seeds through the digestive tract of dispersers can have additional benefits such as removal of the pulp, which can inhibit germination and break dormancy by mechanical or chemical scarification, in addition to seeds being deposited with fecal matter as fertilizer (Traveset et al., 2007).

Despite the several benefits from the plant-frugivore interaction, many fruit-eating animals, especially granivores, can act as seed predators. Seed predation may affect plant reproductive success and is one of the factors that control the population growth of plant species (Bartimachi et al., 2008).

The model proposed by Janzen (1970) and Connell (1971) predicts that a large concentration of seeds and seedlings near the parent tree may increase the action of predators in these sites, increasing seed mortality and reducing the establishment of new individuals, which could result in a non-clustered population. However Hubbell (1980) suggested that when the quantity of seeds under the parent tree is extremely high, even with intense activity of predators in this site, a large number of seedlings could reach maturity, resulting in clustered populations. The massive seed production may satiate seed predators, resulting in a negative correlation between predation and density of seeds (Allmen et al., 2004; Bartimachi et al., 2008). For many species, this may be one of the most important strategies to avoid predation (Pedroni et al., 2002).

In addition to high seed production, characteristics developed during the evolutionary history of plants such as seed hardness and/or presence of chemical substances (alkaloids and terpenes), are associated with defense mechanisms that prevent the action of predators, mainly before dispersion (Janzen, 1971). On the other hand, after dispersion, when seeds are already on the ground, the removal of the pulp or aril by attine ants has been suggested to reduce seed mortality by decreasing fungal attack (Ohkawara and Akino, 2005; Oliveira et al., 1995).

An approach to examine seed dispersal may be to assess the probability of frugivores to remove fruits and deposit seeds in favorable sites for germination (Côrtes et al., 2009). However, to fully understand the dispersal process, information on the life stages of the plant after dispersal is needed, such as germination, seedling establishment, survival and growth of juvenile and adult trees (Godínez-Alvarez and Jordano, 2007).

Buchenavia tomentosa Eichler (Combretaceae) is a tree ranging from 5 to $12 \mathrm{~m}$ in height. Its fruits are elliptic or spherical drupes with diameter ranging from 2 to $5 \mathrm{~cm}$, yellow fleshy pericarp, sweet when ripe, and stony endocarp with one single seed. This species usually occurs in cerradão, semi-deciduous forest, riparian forest, gallery forest, dry forest, and cerrado (Mendonça et al., 2008). According to the floristic analysis by Ratter et al. (2003), B. tomentosa was recorded in 81 of 376 areas of cerrado. Although $B$. tomentosa is widely distributed in cerrado, low abundance has been observed in areas of cerrado sensu stricto (Marimon et al., 2006; Scolforo, 2008). However, in cerrado sensu stricto of Serra Azul State Park (PESA) in Barra do Garças, Midwest Brazil this species is very abundant and has the highest absolute density with 106 individuals per hectare (Ribeiro et al., 2012). In this study, we assessed fruit production and seed dispersion, predation and germination of $B$. tomentos $a$ to examine the relationships of these processes with the high abundance of adult individuals. We then asked the following questions: 1) What are the seed dispersers and predators of $B$. tomentosa? Based on the dispersal syndromes described by Van der Pijl (1982), fruit size and other morphological characteristics (see description in methods) suggest that seed dispersal is carried out by bats or other terrestrial or arboreal mammals. However most characteristics of fleshy fruits may be explained by phylogenetic inertia or by pressure of environmental factors, except fruit size, which has been positively correlated with disperser size (Lord, 2004). Thus, we predict, based on fruit size, that seed dispersal is carried out by large vertebrates. In addition, the stony endocarp of $B$. tomentosa fruit suggests that rodents act as seed predators, as they have the ability to break the endocarp; 2) Does the removal of diaspores on the ground vary with the distance from the parent tree and the fruiting period? Based on the Janzen-Connell model, we expect to find higher predation rates during the peak of fruiting (Bartimachi et al., 2008); 3) Does the passage of $B$. tomentosa seeds through the digestive tract of frugivores or the removal of pulp by animals affect their germination potential? Since the removal of the fleshy pulp that wraps diaspores increases the probability of seed survival and germination (Traveset et al., 2007), the passage of seeds through the digestive tract of frugivores and cleaning by ants can positively influence the fate of seeds (Christianini et al., 2007; Oliveira et al., 1995). Thus, seeds without pulp may be less attacked by fungi and have higher germination rates than those of intact fruits.

\section{Methods}

\subsection{Study site}

This study was carried out in the Serra Azul State Park (PESA), which comprises 11,002 ha in Barra do Garças, Mato Grosso State. The observations and experiments were conducted in an area of cerrado sensu stricto of 
approximately 30 ha $\left(15^{\circ} 50 ' 53.90\right.$ " S - 52 $16^{\circ} 5.94$ ” W and $15^{\circ} 51$ '25.07' S - 52 $15^{\prime} 47.08^{\prime}$ ' W), and altitudes between 522 and $572 \mathrm{~m}$. According to the Köppen classification, the climate of the region is Aw, with two well-defined seasons: rainy (October to April) and dry seasons (May to September). The mean annual rainfall in PESA is $1528 \mathrm{~mm}$ and the mean temperature $25.5^{\circ} \mathrm{C}$ (Pirani et al., 2009). In PESA, savannas, forests, and grasslands are found. The largest phytophysiognomies in area are: cerrado rupestre (savanna on rocky soil) and cerrado sensu stricto (Sanchez and Pedroni, 2011). In a floristic and phytosociological survey of trees conducted in one hectare in the same area of cerrado sensu stricto as this study, 1304 individuals from 37 families, 60 genera, and 86 species were found. B. tomentosa had the highest importance value in the community (Ribeiro et al., 2012).

\subsection{Fruit productivity}

Fruit production of $B$. tomentosa was estimated with collectors of $0.25 \mathrm{~m}^{2}$. Six fruiting trees (isolated from other $B$. tomentosa trees) were randomly drawn. Under each tree, five collectors were installed to cover the entire area of the crown. During the period of ripe fruit drop, collectors were emptied weekly and fruits counted and classified as intact or predated (broken or perforated seeds). Individual productivity was calculated as $\mathrm{P}_{\mathrm{i}}=\left(\mathrm{a}_{\mathrm{i}} \times \mathrm{fc}_{\mathrm{i}}\right) \cdot \mathrm{ac}_{\mathrm{i}}^{-1}$, where $\mathrm{a}_{\mathrm{i}}$ is the area of crown of the individual i in $\mathrm{m}^{2}, \mathrm{fc}_{\mathrm{i}}$ is the total of fruits found in the collectors under the individual, and $\mathrm{ac}_{\mathrm{i}}$ is the total area of collectors of individual $\mathrm{i}$ in $\mathrm{m}^{2}$. Fruit productivity per hectare was calculated by multiplying the mean production of the six individuals by the number of adult individuals found in one hectare in the study area.

\subsection{Seed dispersion and predation}

To identify the dispersers and predators of $B$. tomentosa seeds during the months of ripe fruit production were used: (1) focal observation - 28 trees (focal-trees) with large fruit crops were monitored. (2) transect - weekly, trails were walked and animal species consuming fruits were recorded as well as their behaviors. Direct observations were carried out with $8 \times 21 \mathrm{~mm}$ and $50 \times 50$ binoculars. Observation sessions were carried out in non-consecutive days during the day (06:00-12:00 or 13:00-18:00) and night (19:00-23:00 or 19:00-06:00), totaling $280 \mathrm{~h}$ and $350 \mathrm{~km}$ of diurnal observations in transects, $140 \mathrm{~h}$ of diurnal and $51 \mathrm{~h}$ of nocturnal observations on focal-trees.

Fecal samples containing $B$. tomentosa seeds were collected and seeds were separated, counted, weighed, and evaluated for damage (Golin et al., 2008). Intact seeds (with no apparent damage) were considered potentially dispersed. To evaluate occurrence of secondary dispersion by ants, the mass of seeds found under the crown of three $B$. tomentosa trees and of those carried by ants were measured. Individuals of different castes were collected for later identification. The distance from the edge of the crown to the ant nest where seeds were transported to was also measured.
On three nights during the peak of fruiting, two mist nets $(12 \times 2.5 \mathrm{~m}$ and $7 \times 2.5 \mathrm{~m}$ both with $40 \mathrm{~mm}$ screen mesh) were set up at 18:00 and removed at 23:00, when bats have a peak in activity. Nets were set up perpendicularly to trails at one meter from the ground near fruiting $B$. tomentos $a$ trees. After each bat was captured, the ground near the net was inspected for dropped fruits. All bats captured were photographed and measured for identification, placed in cotton bags for approximately 30 minutes and released. Droppings passed in the cotton bag were washed in filter paper, air dried, and examined for remnants of fruits.

In order to observe signs of pre-dispersal predation by insects, 60 ripe fruits were collected from the crown of trees and placed in covered containers with holes for aeration. Weekly, fruits were inspected for emerged insects. Perforated seeds indicating the emergence of adults from the seeds were considered predated by insects. Adult insects were fixed for later identification.

An experiment to examine the removal of fruits was carried out between June and November 2009 using three approaches: (1) investigate which animals (vertebrates or invertebrates) interact with fruits; (2) investigate whether the distance from the parent tree $(0,5,10$ and $14 \mathrm{~m})$ affects the removal of fruits; and (3) investigate the temporal variation in the removal of fruits during the dispersal period (early, peak, end, post-dispersal). In this experiment, the same six individuals used to estimate fruit production were used. In the surroundings of each individual, 25 experimental stations were placed in equidistant quadrants five meters from each other. In each station, 10 healthy fruits were placed with no protection (control). Among the 25 stations, nine were randomly drawn for the selective exclusion experiment, which consisted of 10 fruits protected by cages. Cages $(42 \times 22 \times 20 \mathrm{~cm}$ and $2 \mathrm{~cm}$ mesh screen $)$ prevented the access of vertebrates (birds, mammals and reptiles), but did not prevent the access of invertebrates. Fruits used in this experiment were collected directly from trees or on the ground and marked with white atoxic odorless corrective liquid, to be distinguished from other fruits available near the experiment. Fruits were placed in the stations with the pericarp, but during the weeks of exposure, the pulp was gradually removed by ants and the experiment continued with only seeds. Fruits not found within a radius of $50 \mathrm{~cm}$ from the station were considered consumed/removed by animals. Fruits and later seeds (after the removal of the pulp) were exposed to animals for 175 days and inspected weekly. The number of fruits (or seeds) removed and, whenever possible, the type of animal responsible for the removal were recorded.

\subsection{Seed germination test}

The experiment was carried out in a greenhouse under natural temperature and light conditions using seeds from healthy ripe fruits collected directly from the crown of $B$. tomentosa trees, seeds obtained from tapir dung, and seeds with pulp removed by ants obtained under tree crown. The treatments were: (1) seeds that passed through the digestive tract of tapirs; (2) seeds with pulp removed 
by ants; (3) seeds with pulp (intact fruits); and (4) seeds with pulp removed manually under running tap water. Each treatment consisted of 20 replicates of 10 seeds sown in plastic containers with sandy soil. Seeds and soil were watered daily and examined every ten days, during 194 days for radicle protrusion.

\subsection{Data analysis}

Prior to statistical analysis, homogeneity of variance and normality were tested. Non-parametric tests were used when necessary (Zar, 2010). To analyze the records of observations of dispersers and predators, descriptive statistics were used. For seeds present in the tapir dung samples, the percentage of occurrence was calculated $\left(\mathrm{PO}=\left(\mathrm{n}_{\mathrm{e}} \times 100\right) / \Sigma \mathrm{n}_{\mathrm{e}}\right)$, where $\mathrm{n}_{\mathrm{e}}$ is the number of occurrence of the species in fecal samples and $\Sigma n_{e}$ is the sum of occurrences of all species, indicating the importance of the fruit among other items (Golin et al., 2008). The $t$ test was used to compare the mass of seeds found under the crown of trees with seeds dispersed by ants to the nests. The relationship between $B$. tomentosa seed mass and the distance of dispersion by ants was analyzed with the Pearson's correlation (Zar, 2010). Differences among the number of intact seeds, seeds predated by beetles, and seeds predated by macaws (pre-dispersal predation) were examined with the Kruskal-Wallis test (Zar, 2010). Fruit removal was analyzed using three approaches: (1) Fruit removal in selective exclusion and open (control) treatments were compared with paired t test (Zar, 2010). (2) Differences in distances of removed fruits from adult individuals $(0,5,10$, and $14 \mathrm{~m})$ were compared with an analysis of variance (ANOVA) (Zar, 2010). (3) Differences in the number of fruits removed during the fruiting period according to the intensity of phenophase (early, peak, end, after fruiting) were analyzed with the Kruskal-Wallis test (Zar, 2010). For each germination treatment we calculated: 1) germinability $\left(G=n_{g} / n_{s} \times 100\right)$, where $n_{g}$ is the number of seeds germinated and $n_{s}$ is the number of seeds sowed (Santana and Ranal, 2004); 2) the Germination Speed Index $\left(\mathrm{GSI}=\Sigma \mathrm{n}_{\mathrm{i}} / \mathrm{t}_{\mathrm{i}}\right)$, with $\mathrm{t}_{\mathrm{i}}$ as the time between the beginning of the experiment and the i-th observation and $n_{i}$ is the number of seeds that germinated in time $t_{i}$ (Santana and Ranal, 2004) and 3) Mean Germination Time $\left(\mathrm{MGT}=\Sigma \mathrm{n}_{\mathrm{i}} \times \mathrm{t}_{\mathrm{i}} / \Sigma \mathrm{n}_{\mathrm{i}}\right)$, where $\mathrm{t}_{\mathrm{i}}$ is the time between the beginning of the experiment and $i$-th observation and $n_{i}$ is the number of seeds that germinated in time $t_{i}$ (Santana and Ranal, 2004). The effects of treatments on germinability (G) were examined with the Kruskal-Wallis test, while GSI and MGT were analyzed with ANOVA, and means compared a posteriori with the Tukey test (Zar, 2010).

\section{Results}

\subsection{Fruit productivity}

Fruiting occurred between March and October. Fruit maturity, characterized by color change from green to yellow and fruit dropping only began in June. The mean size of mature fruits was $4.1 \pm 1.0 \mathrm{~cm} \times 3.3 \pm 0.6 \mathrm{~cm}$ and seed mass, $3.8 \pm 2.1 \mathrm{~g}(\mathrm{~N}=50)$. The peak of fruiting in the population occurred between July and the first half of September (Figure 1). The estimated productivity was $12,877 \pm 7,195$ fruits.individual $^{-1}$ and total annual productivity was $1,365,015 \pm 762,670$ fruits.ha ${ }^{-1}$.

\subsection{Seed dispersal and predation}

Eight animal species were recorded during direct and indirect observations interacting with $B$. tomentosa diaspores (Table 1). The main disperser was Tapirus terrestris (Linnaeus, 1758) - Mammalia: Tapiridae, while Atta sexdens (Linnaeus, 1758) and Atta laevigata (F. Smith, 1858) - Hymenoptera, Formicidae were considered occasional dispersers. Ara ararauna (Linnaeus, 1758) and Ara chloropterus (Gray, 1859) -Aves: Psittacidae and Amblycerus insuturatus (Pic, 1902) Coleoptera, Bruchidae, in addition to an unidentified rodent, were considered seed predators.

During the fruiting period of $B$. tomentosa, 105 tapir dung samples (T. terrestris) were collected and $60 \%$ contained $B$. tomentosa seeds, representing the highest percentage of occurrence $(\mathrm{PO}=51.28 \%)$. Of the 2,961 seeds found in fecal samples, 2,808 (94.83\%) were $B$. tomentosa seeds. A mean of $46.80 \pm 42.31 \mathrm{~B}$. tomentosa seeds were found per sample and $100 \%$ of them were apparently intact after passing through the digestive tract of tapirs. A total of $5.1 \mathrm{Kg}$ of $B$. tomentosa seeds was retrieved, representing $88.95 \%$ of the mass of seeds found in feces.

The leafcutter ants $A$. sexdens and $A$. laevigata were observed under the crown of $B$. tomentosa trees transporting parts of the pericarp or small whole fruits. Diaspores were abandoned by ants (A. sexdens) near their nests and on trails $(10$ to $30 \mathrm{~m})$ between the crown of trees and the nest entrance. The mean mass of seeds $(0.90 \pm 0.35 \mathrm{~g}$; $\mathrm{N}=580$ ) dispersed by ants was significantly lower than the mass of seeds $(1.96 \pm 0.28 \mathrm{~g} ; \mathrm{N}=100)$ that remained under the crown $(t=28.48 ; g l=678 ; p<0.05)$. A negative correlation was found between seed mass and distance

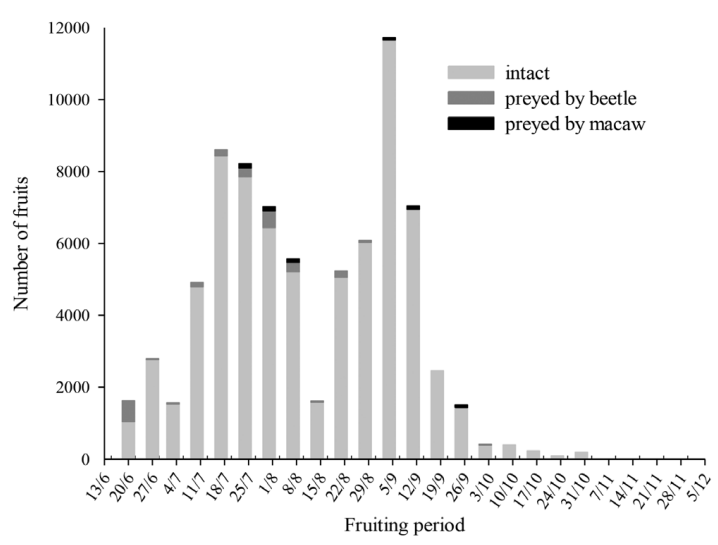

Figure 1. Fruit production of six adult trees Buchenavia tomentosa during fruiting period (ripe fruits) in cerrado sensu stricto, Serra Azul State Park, Barra do Garças, Midwest Brazil. 
Table 1. Animals observed feeding on fruits and seeds of Buchenavia tomentosa (Combretaceae) in cerrado sensu stricto of the Serra Azul State Park, Barra do Garças, Midwest of Brazil.

\begin{tabular}{|c|c|c|}
\hline $\begin{array}{c}\text { Species } \\
\end{array}$ & Behavior & Function \\
\hline Amblycerus insuturatus (Pic, 1902) & $\begin{array}{l}\text { Consumes endosperm and emerges from the seed } \\
\text { embryo }\end{array}$ & Pre-dispersal predator \\
\hline Ara ararauna (Linnaeus, 1758) & $\begin{array}{l}\text { Diurnal - feeds on seeds and drop pulp fruit under } \\
\text { canopy tree }\end{array}$ & Predator \\
\hline Ara chloropterus (Gray, 1859) & $\begin{array}{l}\text { Diurnal - feeds on seeds and drop pulp fruit under } \\
\text { canopy tree }\end{array}$ & Predator \\
\hline Atta laevigata (F. Smith, 1858) & $\begin{array}{l}\text { Mostly Nocturnal - collect the pulp of the fruit } \\
\text { and disperse seeds over short distances }\end{array}$ & Occasional disperser \\
\hline Atta sexdens (Linnaeus, 1758) & $\begin{array}{l}\text { Mostly Nocturnal - collect the pulp of the fruit } \\
\text { and disperse seeds over short distances }\end{array}$ & Occasional disperser \\
\hline Mazama gouazoubira (Fischer, 1814) & $\begin{array}{l}\text { Mostly Diurnal - Feeds on fallen fruits - } \\
\text { consumed the flesh and spitting the seeds or } \\
\text { whole swallows }\end{array}$ & Undefined \\
\hline Tapirus terrestris (Linnaeus, 1758) & $\begin{array}{l}\text { Nocturnal - Feeds on fallen fruits, swallows } \\
\text { whole fruit and defecate seeds }\end{array}$ & disperser \\
\hline Rodent unidentified & $\begin{array}{l}\text { Nocturnal - Consumes seed from fallen fruits } \\
\text { under the canopy trees }\end{array}$ & Predator \\
\hline
\end{tabular}

dispersed by ants from the boundary of the tree crown $(r=-0.60 ; p<0.05)$.

In the peak of fruit production, when $B$. tomentosa fruits were yellow, macaws began visiting fruiting trees. The consumption of fruits was recorded during 10 visits of $A$. ararauna (always in groups of four to 10 individuals) and three visits of $A$. chloropterus (two to four individuals), mainly in the morning. Usually perched on branches, macaws removed fruits from the tree with their beaks, manipulated fruits with the aid of their claws, breaking seeds and consuming the endosperm and embryo. The peak of macaws' visits occurred between end of July and August, when availability of fruits was highest. Based on the data from collectors, $0.73 \%$ of fruits were estimated to be predated by macaws (Figure 1).

Larvae of the beetle Ambycerus insuturatus were found in fruits collected directly from the crown of trees indicating pre-dispersal predation. In the beginning and peak of the fruiting season, emergence of these insects was higher. About $2.79 \%$ of the fruits from collectors had signs of emergence of adults, with endosperm and embryo completely consumed (Figure 1). Regarding total fruit production, significant differences (Kruskal-Wallis, $\left.H_{(2 ; \mathrm{N}=18)}=14.38 ; p<0.05\right)$ were found among intact seeds $($ median $=12,257.5)$, seeds predated by macaws $(87)$ and by beetles (330). In addition to macaws and beetles, which were predators observed daily, 38 partially eaten seeds were found along with small fragments of the stony endocarp, suggesting predation by rodents.

Grey brocket deer (Mazama gouazoubira) were observed twice consuming $B$. tomentosa fruits, but it was not possible to determine whether they ingested or spat out the seeds. In twelve fecal samples examined, no $B$. tomentosa seeds were found and other food items could not be identified.
Although nine bats of the species Artibeus lituratus (Olfers, 1818): Phyllostomidae and Platyrrhinus lineatus (E. Geoffroy, 1810): Phyllostomidae were captured near fruiting trees, they apparently did not interact with $B$. tomentosa. During nocturnal observations, bats were not observed visiting $B$. tomentosa trees for fruits. In addition, under four feeding perches of bats found in the area, there was no evidence of consumption of $B$. tomentosa fruits.

\subsection{Effect of distance from parent tree}

Of the 1080 fruits used in the paired removal experiment, $40(7.41 \%)$ were removed in the open treatment (control) and eight $(1.48 \%)$ were removed in the selective exclusion treatment. This difference was significant $(t=4.3531$; $g l=53 ; p<0.001)$. In the control stations, fruit removal did not vary with the increase in distance up to $14 \mathrm{~m}$ in relation to the parent tree (ANOVA, $F_{3 ; 74}=0.7774$; $p=0.51030$ ) (Figure 2a). The removal of $B$. tomentosa fruits was also significantly higher after the end of the fruiting period (Kruskal-Wallis, $H_{(3 ; \mathrm{N}=600)}=36.1583$; $p<0.001$ ) (Figure 2b). On the other hand, in selective exclusion stations, fruits were removed only at $5 \mathrm{~m}$ from the parent tree and during the fruiting peak.

After the fruiting peak, all fruits (in control and treatment stations) had the pericarp removed by ants and were no longer removed from the selective exclusion stations. On the other hand, in control stations, seeds (fruit without pericarp) continued to be removed even after the fruiting period (from the twenty-first week) (Figure 3).

The removal of fruits was observed in 85 control stations and five selective exclusion stations. A maximum of five fruits was removed per station. Of all fruits used in the experiments, 1,894 were not removed, of which 231 $(12.20 \%)$ germinated and 1,663 $(87.80 \%)$ were infested by fungi and deteriorated. 

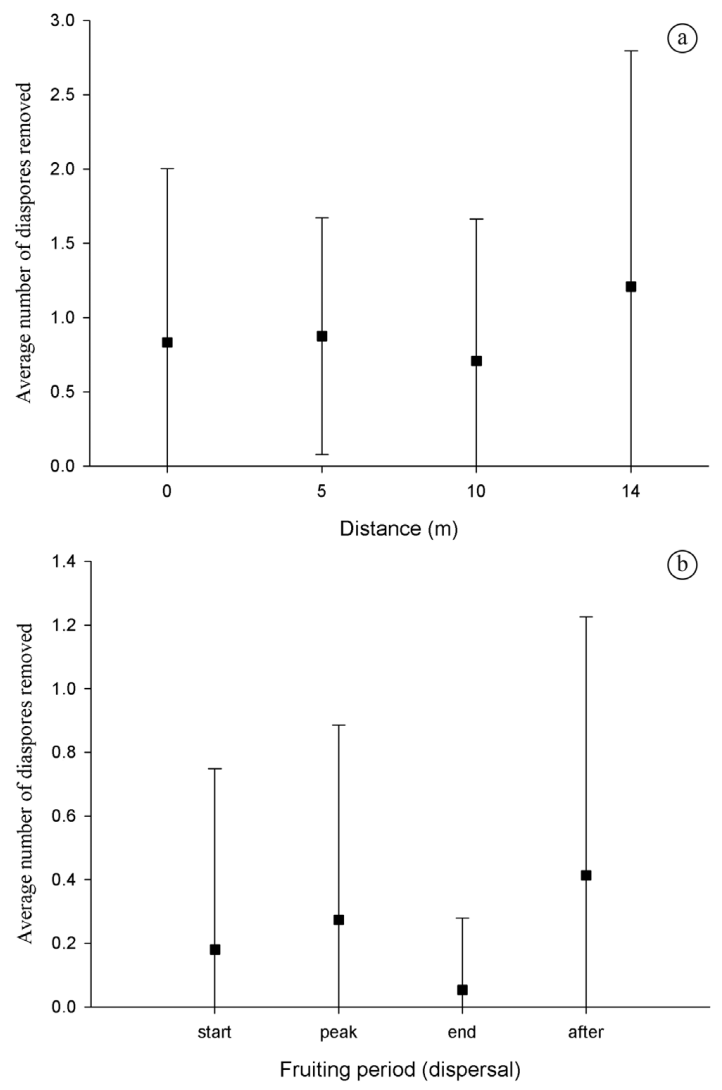

Figure 2. Number of fruits of Buchenavia tomentosa removed in experimental stations with no protection (control) in cerrado sensu stricto, Serra Azul State Park, Barra do Garças, Midwest Brazil: (a) distance from parent tree, (b) fruiting period (ripe fruits).

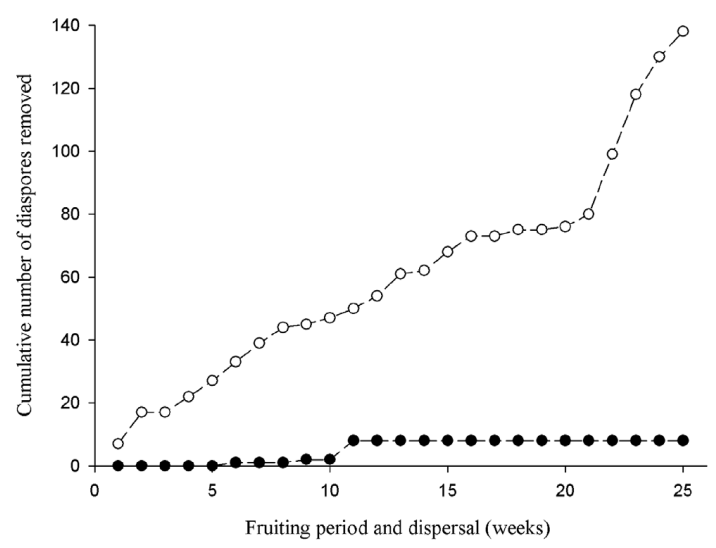

Figure 3. Cumulative number of fruits of Buchenavia tomentosa removed in experimental stations with cage (selective exclusion) (- - ) and experimental stations with no protection (control) $(-\infty)$ during the period of seed dispersal (ripe fruit) in cerrado sensu stricto, Serra Azul State Park, Barra do Garças, Midwest Brazil.

\subsection{Seed germination tests}

Germinability $(\mathrm{G})$ of seeds that passed through the digestive tract of tapirs did not differ significantly from that of seeds with pulp. Germinability of seeds with pulp removed by ants was lower than those of other treatments (Table 2). Germination Speed Index (GSI) of seeds with pulp manually removed was higher than those of other treatments (ANOVA, $F_{3 ; 76}=48.273 ; p<0.001$ ) (Table 2). The GSI of seeds that passed through the digestive tract of tapirs did not differ significantly from those of seeds with pulp or with pulp removed by ants (Table 2). However, the Mean Germination Time (MGT) of seeds (without pulp -removed by animals) was shorter than that of seeds with pulp (ANOVA, $F_{3 ; 76}=29.399 ; p<0.001$ ). Among all treatments tested, seeds with pulp removed manually had the highest germination rate (Table 2). Germinability (G) $($ median $=65 \%)$ of seeds with pulp was lowest than that of seeds without pulp (100\%) (Kruskal-Wallis, $\left.H_{(3 ; \mathrm{N}=80)}=59.4133 ; p<0.001\right)$. The germination peak occurred at day 34 and some seeds took up to 174 days to germinate after sowing. Seeds that did not germinate were attacked by fungi, losing their germination potential.

\section{Discussion}

The high productivity of $B$. tomentosa fruits and fruiting during the dry season, when the availability of fruits of other zoocoric species in cerrado sensu stricto of PESA is low (Pirani et al., 2009), suggest that this species is an important resource for frugivores in the study area. Some populations of frugivores are highly dependent on certain plants, mainly in periods of low availability of food resources (Allenspach et al., 2012). However, few animal species consumed $B$. tomentosa fruits in PESA. This species seems to be important at least to the lowland tapir Tapirus terrestris. In the period studied, B. tomentosa was the main item in the diet of $T$. terrestris, representing more than $94 \%$ of the total of seeds consumed (J. Farias, unpublished data). Only two other studies on frugivory reported seeds of Buchenavia sp. in feces of tapirs (Bodmer, 1991; Golin et al., 2008). The sweet fleshy pulp may be attractive to these animals, but the large availability of these fruits in the environment seems to be the main factor that motivates the high consumption of $B$. tomentosa fruits by tapirs. Another evidence that supports this observation is that only seeds were found in feces of tapirs, after fruit maturation and natural drop, suggesting that the consumption of these fruits occurs only on the ground when fruits are accessible to these animals. According to Bodmer (1991) and Tobler et al. (2010), tapirs forage in different habitats and have a broad diet, but the availability and abundance of fruits are decisive in the choice of food items.

Studies on the diet of $T$. terrestris described these animals as important dispersers, due to the diversity and quantity of seeds that they consume, the long distances traveled from the parent tree (Bachand et al., 2009; Bizerril et al., 2005; Bodmer, 1991; Golin et al., 2008; Tobler et al., 2010), and also because large seeds depend on large fruigivores that 
Table 2. Germinability (G), Germination Speed Index (GSI) and Mean Germination Time (MGT) of Buchenavia tomentosa seeds submitted to different treatments in greenhouse experiment under natural temperature and light conditions (uncontrolled).

\begin{tabular}{lccc}
\hline \multicolumn{1}{c}{ Treatment } & G (\%)* & $\begin{array}{c}\text { GSI** }^{* *} \\
\text { (seeds germinated and } \\
\text { emerged per day) }\end{array}$ & MGT (days)** \\
\hline $\begin{array}{l}\text { Seeds that passed through the } \\
\text { digestive tract of tapirs }\end{array}$ & $40(0-70)^{\mathrm{b}}$ & $1.8 \pm 0.04^{\mathrm{b}}$ & $44.9 \pm 26.8^{\mathrm{bc}}$ \\
Seeds with pulp removed by ants & $25(0-60)^{\mathrm{c}}$ & $1.4 \pm 0.04^{\mathrm{b}}$ & $35.5 \pm 7.8^{\mathrm{c}}$ \\
Seeds with pulp (intact fruits) & $65(30-90)^{\mathrm{b}}$ & $2.0 \pm 0.04^{\mathrm{b}}$ & $69.2 \pm 20.6^{\mathrm{a}}$ \\
Seeds with pulp removed manually & $100(70-100)^{\mathrm{a}}$ & $4.2 \pm 0.04^{\mathrm{a}}$ & $49.1 \pm 12.2^{\mathrm{b}}$ \\
\hline
\end{tabular}

Values followed by the same letter do not differ significantly (Kruskal-Wallis* - median and interquartile range or ANOVA - mean \pm standard deviation**).

may be rare or absent (Lazure et al., 2010). According to quantitative and qualitative criteria suggested by Schupp (1993), tapirs may be considered good dispersers of $B$. tomentosa, as they frequently visited trees, consumed a large quantity of ripe fruits, and defecated viable seeds in favorable sites for germination.

Although the morphological characteristics and the presentation of fruits in the tree suggest dispersal by bats, no indications were found to support that these animals consume the fruits and disperse seeds of $B$. tomentosa. During the study period, fruits of Dipteryx alata Vogel (Fabaceae), Andira cujabensis Benth. (Fabaceae) and Emmotum nitens (Benth.) Miers (Icacinaceae) were found under feeding roosts of bats (J. Farias, personal obs.). These species produce fruits in the same period as B. tomentosa, but no seeds of the latter were found under feeding roosts, suggesting that this species was not part of the diet of bats captured and observed.

In PESA, blue-and-yellow macaws and red-and-green macaws were the only birds observed consuming $B$. tomentos $a$ fruits. The size of the fruit with a large and stony seed appears to constrain the consumption by smaller birds. The macaws which consumed ripe fruits removing them directly from the trees during the peak of fruiting, were considered pre-dispersal predators. Psittacidae is considered a family of birds specialized in seed predation and have been recognized as important pre-dispersal predators in the neotropical region (Francisco et al., 2002). Macaws were the only vertebrate predators directly observed, but rodents may act as predators of $B$. tomentosa seeds as well. In addition to seeds found partially eaten, the removal of diaspores without pericarp during the experiment was an evidence that these animals use these seeds, since all other terrestrial vertebrates observed in the area only consumed the pulp of $B$. tomentosa fruits.

It was not possible to determine whether grey brocket deer act as disperser or predator of diaspores based on the observations of the consumption of $B$. tomentosa fruits. In studies conducted in the Amazon forest, Bodmer (1991) observed that fruits comprise $87 \%$ of the diet of grey brocket deer. However, since these animals do not spit out seeds, most seeds are destroyed in the abomasum, and only small seeds $(5 \times 4 \mathrm{~mm})$ may escape intact. Given the size of $B$. tomentosa seeds, seeds of consumed fruits may have been destroyed in the rumen and therefore not found in the feces examined.

The behavior of leafcutter ants (Atta laevigata and Atta sexdens) show that these animals can be secondary dispersers of small B. tomentosa seeds. Worker ants abandon seeds on the way to and near their nests. Studies conducted by Christianini et al. (2007) in cerrado sensu stricto with different species of plants showed that the mean distances of seed dispersal by ants ranged from 1.5 to $17.7 \mathrm{~m}$. Additional benefits provided by ants while dispersing seeds were the reduction of exposure time under the crown of the parent tree to predators, such as borer insects and rodents. In many cases, ants do not disperse large seeds, but facilitate their survival by cleaning seeds and reducing fungal attack (Ohkawara and Akino, 2005; Oliveira et al., 1995).

Diaspore removal in the selective exclusion stations was lower than that observed in the control stations, where invertebrates as well as vertebrates had access to the fruits, clearly indicating the participation of vertebrates and invertebrates in the system of dispersal/predation of $B$. tomentosa, as recorded in direct and indirect observations of dispersers and predators. The removal of $B$. tomentosa fruits did not vary with an increase in distance from the parent-tree, at least between 0 and $14 \mathrm{~m}$. This result indicates that in the study area, $B$. tomentosa does not fit well to the predation model based on the distance from the parent-tree proposed by Janzen (1970) and Connell (1971). On the other hand, seed predators and dispersers might not have responded to the variation in distance due to the large quantity of diaspores available. The results indicate that in PESA, B. tomentosa seems to have a better fit to the recruitment model proposed by Hubbell (1980). According to this author, when the quantity of seeds under the crown of the parent tree is extremely high, a large number of seeds escapes from the action of predators favoring the formation of clusters of conspecifics. Studies on Euterpe edulis (Allmen et al., 2004) and Syagrus romanzoffiana (Silva et al., 2007) also demonstrated that predation rates may not vary with distance from the parent tree when the 
availability of seeds is high, which may explain at least in part the clustering observed.

In the control stations, the removal of $B$. tomentosa diaspores was higher after the fruiting period, possibly due to the activity of rodents that remained interested in the diaspores without pulp, which were no longer attractive to ants. In the selective exclusion treatment, the removal occurred only during the peak of fruiting, indicating that invertebrates found or were attracted to fruits with pulp when resources were abundant. The variation in fruit removal rates throughout the fruiting season might be associated to the higher attractiveness promoted by the abundance of fruits in the area. Several studies have demonstrated that predation rate tends to increase with the detection of the resource by the predator and with the increase in density of the resource (Bartimachi et al., 2008).

The results of the germination tests indicate that the passage of $B$. tomentosa seeds through the digestive tract of tapirs does not prevent germination. These animals do not have a pre-gastric fermentation chamber and seeds, in general, are not damaged during the intestinal transit (Bodmer, 1991). In a study comparing seeds of Dimorphandra mollis Fabaceae, a species also common in cerrado, that passed through the digestive tract of tapirs and seeds from mature fruits removed from trees, Bizerril et al. (2005) did not find differences in germination rates. In this study, the difference in germination rates observed between seeds defecated by tapirs $(\mathrm{G}=40 \%)$ and those with pulp removed manually $(\mathrm{G}=100 \%)$ might be due to the higher initial hydration of seeds with pulp manually removed with tap water.

Seeds of $B$. tomentosa with pulp manually removed had higher germinability than seeds with pulp, suggesting the presence of germination inhibitors in the pulp of fruits. In addition, pulp removal can promote germination by reducing infestation by fungi and consequently deterioration of seeds, as demonstrated for several tropical plant species (Christianini et al., 2007; Ohkawara and Akino, 2005; Oliveira et al., 1995). In this study, B. tomentosa fruits with pulp were intensely infested by fungi and thus, animals, especially invertebrates that consume the pulp, even without dispersing the seeds, may promote the germination and later establishment of $B$. tomentosa.

These results indicate that the high number of individuals of $B$. tomentosa in areas of cerrado sensu stricto of PESA is due to the high productivity of fruits with viable seeds and high germination potential, presence of effective dispersers (tapirs and ants), and mainly low seed predation rate. All these factors combined, increase the chances of survival even of seeds that fall near the parent tree, resulting in high abundance (approximately 10\% of the trees observed) of B. tomentosa in the area.

\section{Acknowledgements}

We thank R. Leung and L.A.F. Mateus for their helpful comments on the manuscript. C.S. Ribeiro-Costa for identification of beetle and T. Izzo for identification of ants. We thank SEMA for allowing us to work in PESA. COMCERRADO by support.

\section{References}

ALLENSPACH, N., TELlES, M. and DIAS, M.M., 2012. Phenology and frugivory by birds on Miconia ligustroides (MELASTOMATACEAE) in a fragment of cerrado, southeastern Brazil. Brazilian Journal of Biology $=$ Revista Brasileira de Biologia, vol. 72, no. 4, pp. 859-864. http://dx.doi.org/10.1590/ S1519-69842012000500012. PMid:23295515.

ALLMEN, C.V., MORELLATO, L.P.C. and PIZO, M.A., 2004. Seed predation under high seed density condition: the palm Euterpe edulis in the Brazilian Atlantic Forest. Journal of Tropical Ecology, vol. 20, no. 4, pp. 471-474. http://dx.doi.org/10.1017/ S0266467404001348.

BACHAND, M., TRUDEL, O.C., ANSSEAU, C. and ALMEIDACORTEZ, J., 2009. Dieta de Tapirus terrestris Linnaeus em um fragmento de Mata Atlântica do Nordeste do Brasil. Revista Brasileira de Biociências, vol. 7, pp. 188-194.

BARTIMACHI, A., NEVES, J. and PEDRONI, F., 2008. Predação pós-dispersão de sementes do angico Anadenanthera falcata (Benth.) Speg. (Leguminosae-Mimosoideae) em mata de galeria em Barra do Garças, MT. Revista Brasileira de Botânica = Brazilian Journal of Botany, vol. 31, no. 2, pp. 215-225. http:// dx.doi.org/10.1590/S0100-84042008000200004.

BIZERRIL, M.X.A., RODRIGUES, F.H.G. and HASS, A., 2005. Fruit consumption and seed dispersal of Dimorphandra mollis Benth. (Leguminosae) by the lowland tapir in the Cerrado of central Brazil. Brazilian Journal of Biology $=$ Revista Brasileira de Biologia, vol. 65, no. 3, pp. 407-413. http://dx.doi.org/10.1590/ S1519-69842005000300005. PMid:16341418.

BODMER, R.E., 1991. Strategies of seed dispersal and seed predation in amazonian ungulates. Biotropica, vol. 23, no. 3, pp. 255-261. http://dx.doi.org/10.2307/2388202.

CHRISTIANINI, A.V., MAYHÉ-NUNES, A.J. and OLIVEIRA, P.S., 2007. The role of ants in the removal of non-myrmecochorous diaspores and seed germination in a neotropical savanna. Journal of Tropical Ecology, vol. 23, no. 3, pp. 343-351. http://dx.doi. org/10.1017/S0266467407004087.

CONNELL, J.H., 1971. On the role of natural enemies in preventing competitive exclusion in some marine animals and in rain forest trees. In: P.J. DEN BOER and G.R. GRADWELL, eds. Dynamics of number in populations. Wageningen: Centre for Agricultural Publishing and Documentation, pp. 298-312.

CÔRTES, M.C., CAZETTA, E., STAGGEMEIER, V.G. and GALETTI, M., 2009. Linking frugivore activity to early recruitment of a bird dispersed tree, Eugenia umbelliflora (Myrtaceae) in the Atlantic rainforest. Austral Ecology, vol. 34, no. 3, pp. 249-258. http://dx.doi.org/10.1111/j.1442-9993.2009.01926.x.

FRANCISCO, M.R., LUNARDI, V.O. and GALETTI, M., 2002. Massive seed predation of Pseudobombax grandiflorum (Bombacaceae) by parakeets Brotogeris versicolurus (Psittacidae) in a forest fragment in Brazil. Biotropica, vol. 34, no. 4, pp. 613-615. http://dx.doi.org/10.1111/j.1744-7429.2002.tb00582.x.

GODÍNEZ-ALVAREZ, H. and JORDANO, P., 2007. An empirical approach to analyzing the demographic consequences of seed dispersal by frugivores. In: A. DENNIS and D. WESTCOTT, eds. Seed dispersal: theory and its application in a changing world. Wallingford: CABI Publishing, pp. 391-406. 
GOLIN, V., SANTOS-FILHO, M. and PEREIRA, M.J.B., 2008. Frugivoria e dispersão de sementes por antas (Tapirus terrestris, Perissodactyla, Mammalia) em uma área de Cerrado no Mato Grosso. In: J.E. SANTOS and C. GALBIATI, eds. Gestão $e$ educação ambiental: água, biodiversidade e cultura. São Carlos: Rima, pp. 163-178.

HUBBELL, S.P., 1980. Seed predation and the coexistence of tree species in tropical forests. Oikos, vol. 35, no. 2, pp. 214-229. http://dx.doi.org/10.2307/3544429.

JANZEN, D.H., 1970. Herbivores and the number of tree species in tropical forests. American Naturalist, vol. 104, no. 940, pp. 501-528. http://dx.doi.org/10.1086/282687.

JANZEN, D.H., 1971. Seed predation by animals. Annual Review of Ecology and Systematics, vol. 2, no. 1, pp. 465-492. http:// dx.doi.org/10.1146/annurev.es.02.110171.002341.

JORDANO, P. and SCHUPP, E.W., 2000. Seed disperser effectiveness: the quantity component and patterns of seed rain for Prunus mahaleb. Ecological Monographs, vol. 70, no. 4, pp. 591-615. http://dx.doi.org/10.1890/0012-9615(2000)070[0591:SD ETQC]2.0.CO;2.

LAZURE, L., BACHAND, M., ANSSEAU, C. and ALMEIDACORTEZ, J.S., 2010. Fate of native and introduced seeds consumed by captive white-lipped and collared peccaries (Tayassu pecari, Link 1795 and Pecari tajacu, Linnaeus 1758) in the Atlantic rainforest, Brazil. Brazilian Journal of Biology $=$ Revista Brasileira de Biologia, vol. 70, no. 1, pp. 47-53. http://dx.doi.org/10.1590/ S1519-69842010000100008. PMid:20231959.

LORD, J.M., 2004. Frugivore gape size and the evolution of fruit size and shape in southern hemisphere floras. Austral Ecology, vol. 29, no. 4, pp. 430-436. http://dx.doi.org/10.1111/j.14429993.2004.01382.x

MARIMON, B.S., LIMA, E.S., DUARTE, T.G., CHIEREGATTO, L.C. and RATTER, J.A., 2006. Observations on the vegetation of northeastern Mato Grosso, Brazil. IV. An analysis of the Cerrado-Amazonian forest ecotone. Edinburgh Journal of Botany, vol. 63, no. 2-3, pp. 323-341. http://dx.doi.org/10.1017/ S0960428606000576.

MENDONÇA, R.C., FELFILI, J.M., WALTER, B.M.T., SILVA JÚNIOR, M.C., REZENDE, A.V., FILGUEIRAS, T.S., NOGUEIRA, P.E. and FAGG, C.W., 2008. Flora vascular do bioma cerrado: checklist com 12.356 espécies. In: S.M. SANO, S.P. ALMEIDA and J.F. RIBEIRO, eds. Cerrado: ecologia e flora. Brasília: EMBRAPA, vol. 2, pp. 421-1279.

OHKAWARA, K. and AKINO, T., 2005. Seed cleaning behavior by tropical ants and its anti-fungal effect. Journal of Ethology, vol. 23, no. 2, pp. 93-98. http://dx.doi.org/10.1007/s10164-004-0132-4.

OLIVEIRA, P.S., GALETTI, M., PEDRONI, F. and MORELLATO, L.P.C., 1995. Seed cleaning by Mycocepurus goeldii ants (Attini) facilitates germination in Hymenaea courbaril (Caesalpiniaceae). Biotropica, vol. 27, no. 4, pp. 518-522. http:// dx.doi.org/10.2307/2388966.
PEDRONI, F., SANCHEZ, M. and SANTOS, F.A.M., 2002. Fenologia da copaíba (Copaifera langsdorffii Desf. - Leguminosae, Caesalpinioideae) em uma Floresta Semidecídua no Sudeste do Brasil. Revista Brasileira de Botânica $=$ Brazilian Journal of Botany, vol. 25, no. 2, pp. 183-194. http://dx.doi.org/10.1590/ S0100-84042002000200007.

PIRANI, F.R., SANCHEZ, M. and PEDRONI, F., 2009. Fenologia de uma comunidade arbórea em cerrado sentido restrito em Barra do Garças, MT. Acta Botanica Brasilica, vol. 23, no. 4, pp. 10961109. http://dx.doi.org/10.1590/S0102-33062009000400019.

RATTER, J.A., BRIDGEWATER, S. and RIBEIRO, J.F., 2003. Analysis of the floristic composition of the Brazilian cerrado vegetation III: comparison of the woody vegetation of 376 areas. Edinburgh Journal of Botany, vol. 60, no. 1, pp. 57-109. http:// dx.doi.org/10.1017/S0960428603000064

RIBEIRO, M.N., SANCHEZ, M., PEDRONI, F. and PEIXOTO, K.S., 2012. Fogo e dinâmica da comunidade lenhosa em cerrado sentido restrito, Barra do Garças, Mato Grosso. Acta Botanica Brasilica, vol. 26, no. 1, pp. 203-217. http://dx.doi.org/10.1590/ S0102-33062012000100020

SANCHEZ, M. and PEDRONI, F., 2011. Fitofisionomias. In: P.C. VENERE and V. GARUTTI. Peixes do cerrado: Parque Estadual da Serra Azul - Rio Araguaia, MT. São Carlos: Rima, pp. 9-13.

SANTANA, D.G. and RANAL, M.A., 2004. Análise da germinação: um enfoque estatístico. Brasília: Editora Universidade de Brasília, 248 p.

SCHUPP, E.W., 1993. Quantity, quality and the effectiveness of seed dispersal by animals. Vegetatio, vol. 107-108, pp. 15-29.

SCOLFORO, J.R.S., 2008. Características e produção das fisionomias do cerrado em Minas Gerais. In: F.G. FALEIRO and A.L. FARIAS NETO, orgs. Savanas: desafios e estratégias para o equilíbrio entre sociedade, agronegócio e recursos naturais. Brasília: EMBRAPA, pp. 505-610.

SILVA, F.R., BEGNINI, R.M., SCHERER, K.Z., LOPES, B.C. and CASTELLANI, T.T., 2007. Predação de sementes de Syagrus romanzoffiana (Cham.) Glassman (Arecaceae) por insetos na Ilha de Santa Catarina, SC. Revista Brasileira de Biociencias, vol. 5, pp. 681-683.

TOBLER, M.W., JANOVEC, J.P. and CORNEJO, F., 2010. Frugivory and seed dispersal by the lowland Tapir Tapirus terrestris in the Peruvian Amazon. Biotropica, vol. 42, no. 2, pp. 215-222. http://dx.doi.org/10.1111/j.1744-7429.2009.00549.x.

TRAVESET, A., ROBERTSON, A.W. and RODRÍGUEZPÉREZ, J., 2007. A review on the role of endozoochory in seed germination. In: A.J. DENNIS, E.W. SCHUPP and R.J. GREEN, eds. Seed dispersal: theory and its application in a changing world. Oxfordshire: CAB International, pp. 78-103.

VAN DER PIJL, L., 1982. Principles of dispersal in higher plants. Berlim: Springer-Verlag, $215 \mathrm{p}$.

ZAR, J.H., 2010. Biostatistical analysis. London: Prentice-Hall. $944 \mathrm{p}$. 